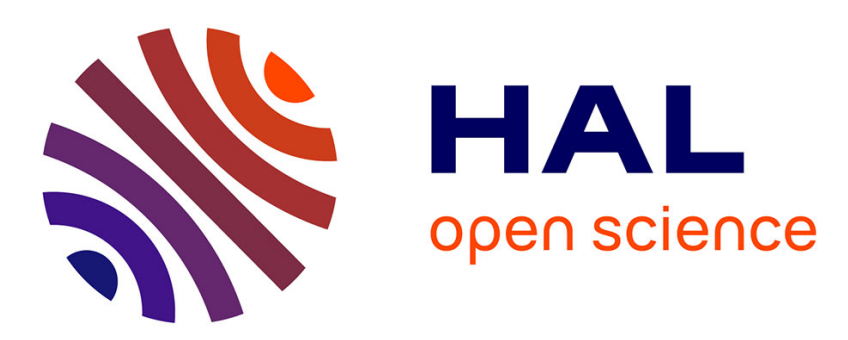

\title{
The Centralization of EU Competition Policy: Historical Institutionalist Dynamics from Cartel Monitoring to Merger Control (1956-91)
}

Laurent Warlouzet

\section{- To cite this version: \\ Laurent Warlouzet. The Centralization of EU Competition Policy: Historical Institutionalist Dynam- ics from Cartel Monitoring to Merger Control (1956-91). Journal of Common Market Studies, 2016, 54 (3), pp.725-741. 10.1111/jcms.12318 . hal-02915603}

\section{HAL Id: hal-02915603 \\ https://hal.science/hal-02915603}

Submitted on 14 Aug 2020

HAL is a multi-disciplinary open access archive for the deposit and dissemination of scientific research documents, whether they are published or not. The documents may come from teaching and research institutions in France or abroad, or from public or private research centers.
L'archive ouverte pluridisciplinaire HAL, est destinée au dépôt et à la diffusion de documents scientifiques de niveau recherche, publiés ou non, émanant des établissements d'enseignement et de recherche français ou étrangers, des laboratoires publics ou privés. 


\title{
The Centralization of EU Competition Policy: Historical Institutionalist Dynamics from Cartel Monitoring to Merger Control (1956-91)
}

\section{LAURENT WARLOUZET}

Since 2019: Paris Sorbonne Université: laurent.warlouzet@sorbonne-universite.fr

At the time of the writing, the author was Marie Curie Fellow at the London School of Economics, Dpt. of International History.

For an updated examination of the history of EU competition policy, see: Laurent Warlouzet, Governing Europe in a Globalizing World. Neoliberalism and its Alternatives following the 1973 Oil Crisis, London, Routledge, 2018, chapter 8 "The Rise of Competition Policy", pp. 156-179.

\begin{abstract}
The contemporary strength of EU competition policy does not stem naturally and mechanically from the Treaty of Rome, nor is it only a consequence of the spread of 'neoliberal' ideas or the single market programme. It is also the product of decades of dynamics underlined by historical institutionalism, which allowed the Commission to secure decisive powers, despite the unwilling- ness of some of the most powerful Member States. In this regard, the two most important corner- stones were Regulations 17/62 on cartels and 4064/89 on mergers. The Commission benefited from the unintended consequences of decisions taken in the Council and from the path dependencies created by Regulation 17/62. It progressively developed a centralized institutional framework with itself at the centre.
\end{abstract}

Keywords: competition Policy; historical institutionalism; commission; history

\section{Introduction}

Competition policy is probably the domain in which the European Commission has enjoyed the largest influence over economic actors, be they companies, consumers or nation-states. The supranational institution has considerable leeway to make decisions alone, and to co-ordinate the decisions of national regulators. Nowadays, the 'modernization' process of EU competition policy involves a 'decentralization' of competences. This evolution cannot be understood without considering the previous dynamic of the centralization of power. The centralization process in competition policy refers to a process by which the Commission has acquired a monopoly, both in terms of information and in terms of decisions on anti-competitive practices. By contrast, competition policy could have been carried out with a stronger role in the decision-making process for Member States and/or for ad hoc independent agencies (at the national and/or at the European level).

First, this article claims that this centralization on the Commission was a surprising outcome, considering the preferences of the larger Member States. Many alternative institutional schemes had been seriously considered, which usually relied on a non-centralized framework. Second, an important explanation of this surprising outcome is the linkage between two milestones pieces of legislation, Regulation 17/62 on cartels and Regulation 4064/89 on mergers. As a result, an exploration of archival material, some of it just recently released, brings new insights for understanding the motivations of the 
main decision-makers. This article relies on the records of the four main actors: the European Commission, France, Germany and the UK. ${ }^{1}$ Third, the concepts of path dependencies and of unintended consequences underlined by historical institutionalism are especially fruitful for understanding this long-term dynamic. Two path dependencies established in 1962 played a role in 1989: the template of centralization and the negative path dependency of the backlog. At many crucial points, decision-makers both in national government and at the Commission took decisions without foreseeing many undesirable unintended consequences.

As a result, this article is a useful complement to a literature which generally puts an emphasis on other dynamics, such as the spread of neoliberal ideas, the single market programme or the pressure on nonstate actors such as companies, either directly or via case law. Section I will review the existing literature to demonstrate the relevance of historical institutionalism for the study of competition policy. Section II will delve into the origins of Regulation 17/62, before Section III examines the negotiations leading to the 'Merger Regulation' of 1989.

\section{Historical Institutionalism and Competition Policy}

\section{The history of European competition policy}

There is now a large body of literature on the history of European competition policy. However, most of it is divided between historical literature on the origins of Regulation 17/62 and political science literature on the dynamics leading towards the Merger Regulation. It reflects the corporatist divide between the two disciplines, even if some academics on both sides try to bridge the gap (Kaiser, 2010). A recent volume on the history of competition policy stops in the early 1980s and does not deal with mergers (Patel and Schweitzer, 2013). Several studies having a wide scope exist, but they do not deal with the decision-making process of both Regulations 17/62 and 4064/89, and consequently do not try explicitly to weave a link between both pieces of legislation. The most convincing studies deal with the role of ideas (Akman and Kassim, 2010) or with the relationships between non-state and supranational actors (Büthe, 2007; McGowan, 2007). The seminal and much-discussed book by David Gerber, for instance, devoted only a few pages to both negotiations (Gerber, 1998, pp. 349- 50 and 380-1). Lastly, the reference study on competition policy, the textbook written by Michelle Cini and Lee McGowan, has an excellent historical chapter, but it is only an introductory survey (Cini and McGowan, 2009, pp. 11-40). Conversely, studies de- voted to detailed examination of the decision-making process in European institutions over a long timeframe generally treat competition policy as a minor field (Moravcsik, 1998, pp. 218-9).

The historical institutionalist approach has sometimes been applied to the history of European competition policy (Armstrong and Bulmer, 1998; Bulmer, 1994; Büthe and Swank, 2007). This article will complement their perspectives by shedding new light on the alternative institutional designs envisaged in the 1960s and on the path dependencies remaining in the 1980s, thus reinforcing the overall historical institutionalist argument. The role of unintended consequences in the development of European competition policy has already been underlined by Stephen Wilks, but only with regard to the modernization process (Wilks, 2005) or as a stimulating but undocumented intuition (Wilks and Bartle, 2002). He called Regulation 17/62 a 'slowly ticking bomb for over 20 years until it exploded in the faces of the national governments during the 1980s'.

\footnotetext{
${ }^{1}$ These official archives are opened after 30 years. For1988-89,FOIA procedures have been used to gain access to archives from the European Commission (thereafter : EUA) and national archives in the UK (thereafter : NA-UK) and in France (thereafter : NA-FR). In Germany, national archives (thereafter : NA-FRG) were used for the 1960s and private archives ('Archiv des Liberalismus' in Gummersbach, thereafter: AdL) for 1988-89. French archives also include the Foreign Affairs archives (thereafter : FAA-FR) and the Michel Debré's paper deposited at Sciences-po.
} 
As a result, there is room for a detailed study of the decision-making process of the crucial milestones in the development of European competition policy. A global and com- prehensive study of the 12 Member States, the five EEC institutions and non-state actors being impossible to undertake in a single article, three choices have been made. In terms of actors, only the Commission and the leading Member States have been studied. This choice is justified by the limited role of the European Parliament in the decision-making process in the period considered. The roles of the European Court of Justice (in particular through the Philip Morris case; Büthe and Swank, 2007) and of business actors (Buch-Hansen and Wigger, 2011), have already been studied with regard to the Merger Regulation.

In terms of case studies, the focus is put on two negotiations. The first is cartel control, since it was the first area of competence developed by the Commission. The second is merger control; its development is relatively easy to study because it was largely created by a single piece of legislation, Regulation 4064/89, whereas other areas have generally been developed progressively by successive landmark decisions and pieces of legislation. Moreover, merger control is a peculiar example of centralization, since there was no legal basis for it in the Treaty of Rome. Last, it became one of DG Competition's most high-profile policies once it had been created.

In terms of actors, the emphasis will be put on Germany, France and the United Kingdom, because they are the most powerful Member States and because they have among the oldest competition policy laws in Europe, set up respectively in 1957 (without taking into account the allied laws), 1953 and 1948. Most of the other Member States, including Belgium and Italy, did not have proper national legislation for a long time. The Netherlands had legislation before the signing of the Rome Treaty in 1957 but it was weakly enforced, as cartelization was widespread until the 1990s (Bouwens and Dankers, 2010). In the Commission, only the activity of the Commissioner for competition and its Directorate General (DG Comp, previously known as DG IV) will be considered.

\section{Historical Institutionalism and EU Policies}

In order to overcome the historian's tendency to indulge in a detailed chronological narrative, recourse to historical institutionalist tools is useful. Historical institutionalism (HI) posits that time matters in explaining the outcome of the decision-making process (Steinmo and Thelen, 1992). It is not similar to narrative history: 'historical institutionalism is less about drawing lessons from or documenting the past than it is about identifying the conditions under which and mechanisms by which the past affects the present and the future' (Fioretos, 2011, p. 383). It posits that temporality has an influence through three crucial mechanisms: 'path dependency', 'critical juncture' and 'unintended consequences' (Hall and Taylor, 1996). The first dynamic means that decision-makers are constrained by decisions taken earlier on, sometimes decades earlier. They do not negotiate on a blank page. 'Path dependencies' make alternative designs more difficult to promote, even those which would, in theory, be more in tune with the actors' preferences. They trigger dynamics of 'positive feedback' and 'increasing return' that reinforce institutions (Streeck and Thelen, 2005, p. 6). This concept is useful to understand the discrepancy between the aims of the main actors - in this case, the reluctance of many decision-makers of the three biggest member states against the Commission's initial proposals - and the outcome of centralization. Path dependencies can also work against the Commission, as in the case of the backlog (see below) which seriously undermined its credibility as an efficient institution. However, this 'negative' path dependency (seen from the European Commission's perspective) paradoxically helped to reinforce the centralization process.

Path dependencies originate during 'critical junctures', which are short periods of times when 'wideranging change is possible' (Capoccia and Kelemen, 2007, p. 352). The aim of this article is to demonstrate that 1962 was such a 'critical juncture', much more than the period of the Rome Treaty, by demonstrating that many 'alternative choices were available to the decision makers' at this point (Capoccia and Kelemen, 2007, p. 369), but not later on. 
'Unintended consequences' mean that the outcome of negotiations can appear disappointing after a first apparent victory. This is, for example, the case when a regulation is not implemented in the way anticipated during its negotiation. As a result, HI aims to use history to understand why actors took decisions which appear, with hindsight, illogical or detrimental to their interests. As Paul Pierson underlined, it is especially suited to the study of European institutions (Pierson, 1996). Within the European institutional framework, national decision-makers are especially constrained by the partial autonomy of supranational institutions, the multiplicity of technical issues to master, the limited timehorizons of national decision-makers and their shift in policy preferences.

Against historical institutionalism, it has been argued that Member States usually have well coordinated European policies which enable them to master the EEC/EU decision- making process and to impose radical reforms, in particular through intergovernmental conferences (Kassim and Menon, 2003, pp. 130-1). Despite these criticisms, HI is especially suited to the study of competition policy, since this field has barely been affected by Treaty revision and had largely been considered as secondary by national officials for most of the period considered. Competition policy developed as a significant public pol- icy in West Germany in the 1960s, but in most other countries only in the 1980s. In the United Kingdom and in France, where provisions had already existed for decades, com- petition policy was often subdued under the influence of more powerful policies such as price policy or industrial policy. As a result, even when the Merger Regulation was negotiated in 1989, competition policy was a new area of expertise, and not a priority for decision-makers. National ministers had changed frequently and did not consider this issue as being at the core of their agenda (except in Germany). Last, the Commission has been especially important in this field since it is one of the first supranational policies, along- side the CAP and the commercial policy.

It is necessary, however, to use HI in a neutral way regarding the balance of power be- tween Member States and the Commission. Indeed, the Commission's officials can also be affected by the dynamics of path dependency and of unintended consequences. The Commission is internally divided along national origins but also with regard to political and economic conceptions.

Recourse to a classical historical methodology, that is to say, the examination of archival records, allows the researcher to go beyond the press releases, speeches and memoirs. With regard to HI, archival records are particularly useful to assess whether decision- makers were really constrained by past agreements, or whether they were free to discuss alternative designs. Taking into consideration the alternatives seriously considered by the decision-makers, that is to say, discussed within the Council either on the proposal of the Commission or of Member States, is important to show that the outcomes - in this case, centralization - are not inevitable, but are the product of a selection process among different alternatives, often forgotten in the subsequent accounts.

\section{The Path Dependencies of 1962}

The foundational years of EEC competition policy, namely between the negotiations of the Rome Treaty in 1956 and the passing of Regulation 17/62 in 1962, have now been thoroughly examined (Bussière, 2007; Hambloch, 2009; Montalban et al., 2011; Pace and Seidel, 2013; Pitzer, 2009; Warlouzet, 2011, pp. 269-338). Drawing on this vast body of literature - which does not use HI concepts explicitly - and on further research in archives, this contribution will focus on the question of centralization between 1956 and 1962. It will underline two points. The first is the contrast between the vague and general provisions of the Treaty of Rome regarding competition policy and the institutional outcome of Regulation 17/62. This point has already been underlined in a few studies (Gerber, 1998, p. 349), but most of them failed to underscore the fact that many alternatives were seriously discussed. Second, the importance of path dependency and of unintended consequences will be underlined by pinpointing the discrepancy between the anticipation of actors during the negotiation of the regulation and its early implementation. 


\section{The Vagueness of the Rome Treaty}

The Treaty of Rome was largely influenced, with regard to the competition policy provisions, by a confrontation between the French and the Germans, whose national experiences contrasted sharply.

The French law of 1953 was embedded in price policy, as its main aim was to fight against 'restrictive practices' that had an inflationary effect. A severe stance was maintained against some types of distribution agreements as they were supposed to hamper the modernization of the distribution sector. Conversely, cartels as such were not particularly discouraged. The 1953 law had established a consultative committee linked to the Ministry of Economics. The cartels were generally cleared, and 'no drastic sanctions' were taken (Riesenfeld, 1962, p. 469).

Germany had no law on its own when the Treaty of Rome was negotiated, except the allied law of 'decartelization'. The law against the restriction of competition was eventually adopted in July 1957 but some of its features were already visible in 1956, when the Treaty of Rome was negotiated. Two of these features contrasted vigorously with the French example. First, competition policy was considered in Germany as crucial in the building of the new democratic and liberal Germany which would break from the past, as the National Socialist era was associated with cartelization (Gerber, 1998, pp. 23265). For ordo-liberalism, a school of thought which influenced many German officials, eco- nomic liberalism was strongly linked to political liberalism and competition policy played a central role in this process. It was part of an 'economic constitution' designed to ensure that individual freedom was guaranteed. Second, the principle of prohibition had already been largely accepted in 1956. It meant that all cartels were banned, unless they were explicitly authorized by an authority. The prohibition principle of the afore- mentioned German law contrasted with the abuse principle adopted in France (all cartels are authorized unless they are explicitly banned). There was no merger control. The Minister of Economics, Ludwig Ehrard, did not want to weaken the industry with stringent provisions against concentrations.

During the Treaty of Rome negotiations, these positions translated into a clash of models. As documented in a $\mathrm{PhD}$ thesis based on French and EU archives, the French proposed a competition policy based on the abuse principle and on the same treatment of all restrictions to competition: cartels, concentration and individual practices (Warlouzet, 2011, pp. 274-5 and 294-6). In 1956, the French officials had in mind the failure of the ECSC's High Authority to tackle the large German companies, and more generally to implement an efficient competition policy (a failure documented in Witschke, 2009), so they considered this field relatively minor within the negotiations. ${ }^{2}$ While they did not want to establish a powerful supranational competition policy, they were interested in controlling concentration as they feared the competition of the larger German companies, even if they did not say so openly. The Germans took the reverse position: they put an emphasis on the fight against cartels, and they were more lenient against concentrations. Above all, Alfred Müller-Armack, the German negotiator and a close collab- orator of Ludwig Erhard, insisted on securing the prohibition principle. In internal documents, he explained that it was compulsory for domestic reasons: if the prohibition principle was not upheld at the EEC level, it could be threatened at the national level. ${ }^{3}$

The two sides agreed on one point: they did not want to give large power to the European authorities in this remit. For the French, competition policy was only a minor field, especially considering the failure of the ECSC competition policy. For the Germans, what was most important was to preserve their future national law, whose long-standing negotiation was not yet completed. That is why both countries accepted the compromise presented by Hans von der Groeben, the president of the group negotiating the articles on competition policy, with the support of the Dutch and Belgians (Büthe and Swank, 2007, 23). ${ }^{4}$ It left the main questions largely unanswered: article 85 EEC (article 101 TFEU) contained the

\footnotetext{
${ }^{2}$ FAA-FR, DECE613, note FG, 14 April 1956; DECE614, note FV, 5 December 1956.

${ }^{3}$ EUA, CM3/236, note Secretariat, debates on 7 September 1956; note of 5 November 1956 by Meyer-Cording; note of 8 November 1956, published in Schulze and Hoeren, 2000, pp. 194-5 and 204-5.

${ }^{4}$ EUA, CM3, document of 20 November 1956 ('groupe du Marché commun').
} 
prohibition principle in the first paragraph, but also the exceptions in the third paragraph. Cartels could be banned according to article 85-1, but also authorized if they fulfilled the criteria of article 85-3 (contribution to technical progress, etc.). This association of a prohibition provision with an important exception looked like the French abuse law. Article 86 EEC (article 102 TFEU) on dominant position was vague and article $87 \mathrm{EEC}$ left the implementation of the first two articles to a further regulation. It was stated that this future regulation should take into account the national laws (article 87-2e) and "the need, on the one hand, of ensuring effective supervision and, on the other hand, of simplifying administrative control to the greatest possible extent' (article 87-2b). In other words, no clear institutional framework was defined by the Treaty.

\section{The Decisive Regulation 17/62}

Regulation 17 in 1962 clarified the uncertainties of the Treaty of Rome in three ways. First, it interpreted article 85 as a ban on cartels. It followed the German interpretation rather than the French theory of 'abuse', despite the fact that the wording of article 85 was somewhat close to article 59 of the French law of 1953. Regulation 17/62 banned all anticompetitive agreements (if capable of affecting intra-EEC trade) unless the Commission was notified. It meant that a procedure dominated by the competition criterion was imposed, whereas the French negotiators pleaded for a system called the 'global economic assessment' of cartels (Warlouzet, 2011, pp. 305-6). It was broader, as it took into account all the economic consequences of a cartel (on the modernization of economic structures, for example). It was close to the criterion of the 'general economic interest'. In the French perspective, competition policy was not erected as an independent public policy relying on its own criteria.

Second, it gave clear priority to the fight against cartels (article 85 EEC) on the monitoring of dominant position (article $86 \mathrm{EEC}$ ). As a result, competition policy progressively asserted itself as a genuine public policy, with its own logic and independent from other fields like industrial, social or regional policy. This stance had been constantly affirmed by the Commissioner for competition, Hans von der Groeben. Third, Regulation 17/62 gave extensive power to the Commission, which received a monopoly on information, via the notification procedure, and on decisions, as the committee of Member State experts was only consultative. As article 85-1 EEC was interpreted as a full prohibition on cartels, an institution was required to grant the exemption of article 85-3 EEC. The Commission fulfilled this role. Again, the German model was probably the closest to the Regulation 17/62 system, even if it was not a pure adaptation, since the Commission was a political institution. Its function was, among others, to propose legislation and not simply to implement it. By contrast, the German competition authority created in 1957 was a purely ad- ministrative authority, albeit with a high degree of independence from the government.

This outcome does not mean that the German national government's conception prevailed, but rather that a reinterpretation of the German experience by the European Commission did. Bonn had different priorities in 1960, when the negotiations over the future regulation began. It wanted to preserve the competences of its national competition authority, the Bundeskartellamt, and thus refused to envisage the centralization of decision-making with the Commission at first. The Bundeskartellamt proposed to follow the German experience more closely, by setting up an independent cartel authority, with less risk of political interference than the European Commission. ${ }^{5}$ Eventually, Bonn altered its stance and accepted the revised proposal of Commissioner von der Groeben.

Alternative schemes were also envisaged by the French negotiators. From the start, they had defended an interpretation of the Rome Treaty based on the abuse principle and a decision-making process associating the Commission and the Member States (Warlouzet, 2011, pp. 304-7). France was not isolated. During the first extensive debate among the six governments on the Commission's proposal in November 1960, France, Italy and Belgium opposed this choice to centralize both the assessment of the

\footnotetext{
${ }^{5}$ NA-FRG,B102/134644, note of 3 October 1960; note on a meeting on 6 October 1960; B102/134647, note Epphardt, 15 June 1961.
} 
agreement and the power to take final decisions under the Commission. ${ }^{6}$ For many actors, it appeared logical to separate both tasks, as in the French experience, or to create an independent authority, as in the German and British cases. The idea of a European cartel authority was aired by the President of the Commission, the German Walter Hallstein, in 1960 in a letter to the Council of Ministers. ${ }^{7}$ The German trade unions (DGB) supported an institutional framework designed to associate societal actors to the decision-making process. ${ }^{8}$

This balance of power evolved in favour of the Commission because of von der Groeben's skills but also for various contingent reasons, including a change of government in Belgium which brought in a socialist government more hostile to cartels. More- over, the French government clearly overestimated its leeway. In a letter to de Gaulle of 9 June 1961, the Prime Minister Michel Debré still thought that it was possible to 'isolate' Germany on cartels. ${ }^{9}$ French officials did not anticipate the outcome of the negotiations, which occurred only six months later.

The outcome of the negotiations has sometimes been considered mainly as a side- effect of an intergovernmental bargain between France (which secured the CAP on 14 January 1962) and Germany (which got the agreement on competition policy; Moravcsik, 1998, p. 218; Pitzer, 2009, p. 407). This inter-governmental bargain certainly played a role, but it does not demonstrate that the Member States got what they wanted, as the gap between the initial aim of the German government and the final regulation shows. Moreover, this bargain was unnecessary to conclude the agreement. According to article $87 \mathrm{EEC}$, the regulation had to be adopted unanimously only during the first period of three years (1958-60). As a result, it could have been adopted by a qualified majority voting in 1961, so France, isolated along with Luxembourg in its opposition, could have been outvoted. In the aforementioned letter of 9 June 1961, Michel Debré, an outspoken adversary of supranationalism, worried about the growing use of qualified majority voting within EEC institutions. ${ }^{10}$ In December, the French Department in charge of co- ordinating European policy explicitly envisaged the scenario of France being outvoted in the Council. ${ }^{11}$ This demonstrates that the threat of qualified majority voting was real.

Commissioner von der Groeben also made concessions. He agreed to alter his initial proposal of 1960 , in particular by taking into account the European Parliament report of Deringer and specific French requests. For example, the French policy against vertical agreements was more severe than that of its neighbours, including Germany (Riesenfeld, 1962, p. 473), as the German law targeted horizontal rather than vertical restraints (Gerber, 1998, p. 295). Thus France secured article 22, which stipulated that, within a year of the regulation's entry into force, the Council (on a proposal of the Commission) was to examine the possibility of making the notification procedure mandatory for certain types of agreements. This clearly meant distribution agreements according to the French interpretation, which was accepted by DG IV. ${ }^{12}$ These additions did not contradict, and even reinforced, the main features of Regulation $17 / 62$, namely a genuine pro-competition approach and full centralization under the Commission.

\section{Path Dependency during Implementation}

The implementation of Regulation 17/62 quickly became a nightmare for the Commission. In April 1963, the Commission received 36,000 notifications, while DG IV had only 78 officials in 1964 (Pitzer, 2009, p. 416; McGowan, 2010, pp. 128-9). As competition policy was still a new field in Europe, setting criteria to gauge the cartels proved to be a near-impossible task. This created a strong and negative path

\footnotetext{
${ }^{6}$ NA-FR, 19790791/264, document from the European Commission on the debate of 29 November 1960.

${ }^{7}$ FAA-FR, RPUE245, Hallstein to the Council, 27 May 1960.

${ }^{8}$ NA-FRG, B102/134647, Deutscher Gewerkschaftsbund, 30 January 1961.

${ }^{9}$ Michel Debré collection, 2DE30, Debré to de Gaulle, 9 June 1961.

${ }^{10}$ Michel Debré collection, 2DE30, Debré to de Gaulle, 9 June 1961.

${ }^{11}$ NA-FR, 19790791/264, note SGCI, 16 December 1961.

12 NA-FR, 1979.0791/264, Verloren van Themaat to Fontanet, 28 October 1960.
} 
dependency for the Com- mission for decades. The DG IV policy was largely reactive rather than proactive, since it had to cope with these notifications (Cini and McGowan, 2009, p. 215).

The origins of this backlog are usually attributed to the notification procedure of Regulation 17/62 but, strictly speaking, this is not exactly the case. In fact, the Commission received only 800 notifications in November 1962. As a result, Commissioner von der Groeben apparently sought to encourage further notifications. ${ }^{13}$ He secured the adoption of Regulation 153/62, which introduced a simplified notification procedure for certain exclusive agreements, and the Commission published a communication on the subject of notification (EEC Commission, 1962). Nevertheless, European business organizations remained wary, as they did not know whether or not they had to notify their agreements. In a letter to UNICE (Union des industries de la Communauté européenne), the main EEC-wide business organization, von der Groeben expressly asked companies to notify their distribution agreements, including those for which the need to notify was uncertain. ${ }^{14} \mathrm{He}$ said that the Commission would be 'moderate' and 'understanding' for the companies which 'trusted' it. This decision greatly contributed to the flow of notification. The vast majority of these (almost 90 per cent) were exclusive dealing agreements.

Von der Groeben probably underestimated the extent of this flood of declarations, and thought that he could count on the support of the Council to get block exemptions (the exemption of a category of agreements from the obligation to notify, in order to clear a large number of cases in one go). However, the Member States did not want to devolve more powers to an authority which had not proved its ability to efficiently implement Regulation 17/62. ${ }^{15}$ Von der Groeben made his first proposal in November 1962, but the first group exemption regulation was adopted only in 1967.

The study of the adoption of Regulation 17/62 and of its early implementation demonstrates that these events of 1956-62 produced a three-fold path dependency: first, the prohibition principle and the focus on cartels meant that competition policy could progressively emerge as an independent public policy, as in the German case; second, the centralization of information and of decision-making under the Commission was a surprising outcome, considering the wording of the Treaty and the alternatives considered by major actors. Critics of this centralization were widespread at the beginning of the negotiations, so the choice of a more decentralized institutional framework could have been perfectly possible. Third, the mismanagement of the notification process led to a backlog problem which affected DG IV for decades. These three dynamics all had a direct influence on the Merger Regulation 20 years later.

\section{The 1989 Merger Regulation}

The Merger Regulation of 1989 empowered the Commission to review all mergers of 'European dimension', i.e. beyond a certain threshold. As it was implemented effectively from the start, by contrast with the ECSC Treaty's merger provisions or Regulation 17/62, it is a clear watershed in the history of European competition policy. As a result, it brought about a large number of studies. They generally underline the role of market dynamics, in particular the momentum of the Single European Act, or the role played by transnational networks of private actors fostering a neoliberal agenda (Buch- Hansen and Wigger, 2011, pp. 78-87). A decisive role is generally attributed to the pressure created by the Philip Morris judgment of 17 November 1987 (Joint cases 142 and 156/84). When the ECJ recognized the right of the Commission to exert a merger control on the basis of article $85 \mathrm{EEC}$, business companies feared for the legal security of their operations. Thus, they put pressure on their national governments to agree on the long- awaiting Merger Regulation, first proposed by the Commission in 1973 but adopted

\footnotetext{
${ }^{13}$ NA-FR, 1979.0791/262, note on the conference of experts, 22-23 November 1962. FAA-FR, DECE1259, note MC, 15 January 1963.

${ }^{14}$ EUA, BAC89/1983/9/213, von der Groeben to de Koster, 23 January 1963.

${ }^{15}$ FAA-FR, RPUE615, note Cuvillier, 11 February 1964.
} 
only in December 1989. This momentum created by the Philip Morris judgment is considered as the most important factor leading to the adoption of the merger control by the most convincing account of the negotiation - either almost exclusively (Büthe and Swank, 2007; Pollack, 2003, pp. 284-91) or in conjunction with other factors, such as the leader- ship of the commissioners for competition (Cini and McGowan, 2009, p. 31; Montalban et al., 2011, pp. 28-9) or Member States' bargaining (Armstrong and Bulmer, 1998, pp. 100-6; Bulmer, 1994; Schwartz, 1993). This article does not dismiss the importance of these factors. Rather, it aims to show the limits of the explanations based on the market dynamic, the decisive role of the path dependencies of Regulation 17/62 and the importance of unintended consequences for French officials.

\section{The Limits of the Market-based Explanations}

The Philip Morris judgment was certainly a major breakthrough, but it was insufficient to bring about a successful conclusion of the negotiation, for two reasons. First, the deterrence argument (the fact that the Commission could use article 85 and 86 directly, thus putting pressure on the Member States to agree on a regulation) had existed before Philip Morris. The French archives reveal that Commissioner Sutherland had already used this threat before this ruling, at the end of 1985, and that the French officials took this seriously. ${ }^{16}$ Second, even the legal service of the Commission considered, in its internal opinion on the Philip Morris judgment, that it was insufficient to provide a sound basis for a sound European merger policy. ${ }^{17}$

The more general explanation about the role of the single market dynamic is also important but insufficient. There was no article reinforcing competition policy in the Single European Act of 1986, which by contrast insisted on regional policy, industrial policy and research and technology policy. It was the implementation of the SEA and the single market dynamic that were important (Jabko, 2006, p. 19). Qualified majority voting was not extended to merger control. Indeed, a completion of the single market without a merger regulation would have been perfectly possible, as many important actors were contemplating a new failure of this 16-year-long negotiation in 1989.

In April 1989, the new Commissioner for competition, Leon Brittan, asked DG IV about the merger case under review and for possible new cases. The note from Brittan's cabinet elaborated: 'The reason for this initiative is Sir Leon's concern that we may be losing momentum on the Merger Regulation. If no progress is made on 3 May, we should also consider the preparations of guidelines on the application of Article 85 and 86 . We could also make public the fact that we are preparing them' ${ }^{18}$ Brittan clearly envisaged the failure of the negotiations. He reflected on an alternative to the regulation, even though this move was also a tool to put pressure on the Member States.

The same uncertainty over the conclusion of the negotiations also loomed large in the national officials' reflections. Some French officials cast doubts on the Commission's ambitions for the same reasons as in the 1960s: the proposed regulation was too supranational and too market-friendly. In October 1989, senior officials from the Ministry of Economics and Finance (including Jean-Claude Trichet as head of the Treasury) warned that a failure of the negotiations was better than poor legislation. ${ }^{19}$

In London, the official position was still negative in early November 1989: 'The UK continues to maintain its general reservation on the principle of a Regulation'. ${ }^{20}$ The staunchest opponent was Germany, which feared that the European merger regime could undermine its own national merger regime, in particular if it was more lenient. ${ }^{21}$ In July 1989, in a meeting between Brittan and national

\footnotetext{
${ }^{16}$ NA-FR, 19900452/25, notes SGCI, 13 November 1985 and 25 November 1985.

${ }^{17}$ EUA, BAC104/1993/159, note Dewost, 25 January 1989.

${ }^{18}$ EUA, BAC104/1993/160, note Jonathan Faull, 26 April 1989.

${ }^{19}$ NA-FR, 19900452/29, Trichet for the Minister, note of 4 October 1989.

${ }^{20}$ NA-UK (FOIA), note by Redwood (DTI), 3 November 1989.

${ }^{21}$ AdL, A49/272, fax BMWi, meeting of the economic Commission of the Bundestag on 25 October 1989.
} 
officials, the German representative put forward the idea of a 'European antitrust office'. ${ }^{22}$ The old idea of an independent com- petition agency remained present at the highest level, threatening the Commission's ambitions of centralization. Until the last moment, Germany's agreement was not guaranteed. In the end, purely political factors played an important role in Bonn's final acquiescence. It is well known that the quick pace of reunification after the fall of the Berlin Wall on 9 November 1989 worried some EEC member states. In late November and early December, the priority of Kohl and Genscher was to dissipate the impression that Germany 'emerged as a brake on the European unification process' (Dyson and Featherstone, 1999, p. 364). They felt compelled to reaffirm the West German European credentials during the Strasbourg summit of 8-9 December 1989, in particular by agreeing to set a date for an intergovernmental conference on the EMU. What is less well known is that, according to the declaration of Minister of Economics Helmut Haussmann and his Secretary of State Otto Schlecht to the FDP Bundestag group, the question of the merger regulation 'played a role' during the European Council. ${ }^{23}$ Bonn probably considered it impossible for Germany to be the only country to block the merger regulation negotiations in these circumstances.

\section{The Role of Negative Path Dependencies}

Paradoxically, the Commission was also able to benefit from negative path dependencies, that is to say institutional legacies triggered by the critical juncture of 1962 that put into question its administrative efficiency. The most important was the backlog of Regulation 17/62. Even though it was milder in the 1980s than in the late 1960s, it was still weighing heavily on DG IV resources. There were still more than 3,500 cases pending on 31 December 1986 (Commission of the European Communities, 1987, p. 55). When he became Director General for Competition in 1990, Claus-Dieter Ehlermann still considered his main task with regard to cartels to be alleviating the burden of the remaining 3,000 cases awaiting a decision. ${ }^{24}$ This led important Member States to believe that the merger regulation would probably not lead to an assertive policy. When the Director General of DG IV, Caspari, summarized the negotiation for the new commissioner in January 1989, he underlined: 'Particularly from countries in this group [FRG, UK, France], the argument has been put forward that the Commission services are not capable of treating in depth the great number of notifications expected'. ${ }^{25}$ In Germany, almost everybody anticipated a lenient merger policy. For example, the debate within the FDP group of the Bundestag on 7 November 1989 revolved around the consequences of this possible weak policy. Some feared that it would be a threat to the German merger policy. They supported the position of the Bundeskartellamt, which was very critical. By contrast, Haussmann and Schlecht, who negotiated the regulation in Brussels, appeared far less hostile to mergers. Schlecht explicitly criticized the Bundeskartellamt's position and underlined the necessity for companies to grow. ${ }^{26}$ At the same time, the Minister of Economics had authorized a controversial German merger between Daimler-Benz and MBB, despite the Bundeskartellamt's opposition to it. In any case, none of them anticipated a smooth and bold merger policy.

The backlog also helped to overcome fears on the part of some French officials of an overactive European merger policy. Overall, bar notable exceptions like the aforementioned Trichet note, a sizeable number of French officials were relatively confident in the last stage of the negotiations. They anticipated a lenient policy, more favourable to mergers than both the direct application of article 8586 and of certain foreign legislations. A recurring theme was the possibility of using the merger regulation to 'avoid the protectionism of the Bundeskartellamt' ${ }^{27}$ This comment dates back to 1988 and applies to the Bundeskartellamt's prohibition of a takeover of a German company (Grunding) by a French one (Thomson) in 1983. The confidence of those French officials can appear strange retrospectively, as it occurred in the context of a growing assertion of the EEC state aid policy which

\footnotetext{
${ }^{22}$ EUA, BAC104/1993/160, note DG IV, meeting on 11 July 1989.

23 AdL, A49/273, meeting of the working group II, 12 December 1989.

${ }^{24}$ Interview of the author with Claus-Dieter Ehlermann, Brussels, 31 July 2013.

${ }^{25}$ EUA, BAC104/1993/159, Caspari to Brittan, 18 January 1989.

${ }^{26}$ AdL, A49/272, note of 7 November 1989 ; 'Zweites Kartte-Papier von 2.11.89'.

${ }^{27}$ NA-FR, 19900452/27, note SGCI, 15 November 1988.
} 
was targeting France in particular. The memory of the implementation of 17/62 certainly played a role, both with the backlog and with the subsequent focus on exclusive dealing agreements, which concurred with French priorities much more than with German ones. For example, the German representative at the advisory commit- tee voted against Grunding-Consten, the first decision to ban a cartel, made in $1964 .^{28}$ Germans supported exclusive dealing agreements as they were useful to penetrate foreign markets. As a result, the Commission's cartel policy resulting from the decisions of 1962 helped the French to accept centralization in the 1980s.

Another consequence of the backlog was the concentration of the debate on the means of ensuring effective implementation. Caspari worried about the 'administrative work- load' and the need to find ways to alleviate it within the procedure set out by the future regulation. ${ }^{29}$ In the negotiation with Member States, Commissioner Brittan insisted on the necessity to create simple and quick procedures and to provide more staff to DG IV to implement the regulation. ${ }^{30}$ Likewise, in Paris, French officials worried about the risk of a 'bureaucratic procedure' and about the necessity to ensure a quick decision by the Commission. ${ }^{31}$

This is why the debate concentrated on the question of the dual implementation of national and European authorities, and on the delay of the procedure (in order to ensure a quick assessment of mergers). Sutherland had already progressed on these issues, but it was Brittan who secured the final agreement, with further concessions regarding the exclusive implementation of the regulation to mergers and the so-called 'German' clause concerning national authorities. ${ }^{32}$ This focus meant that two other features of the regulation, the centralization under the Commission and the focus on the competition criterion, were less discussed. Many countries, including France and Spain, wanted to include non-competition criteria but their strategies were uncoordinated..$^{33}$ As a result, the final outcome was disappointing in this regard, with a competition criterion largely bolstered (Armstrong and Bulmer, 1998, 105). To conclude, the backlog inherited from Regulation 17/62 helped to allay the fears of an overactive merger policy from France, which was a potential opponent of a competition-only regulation, but also of certain German officials, who were not so hostile to mergers.

\section{Unintended Consequences for France}

The conclusion of the Merger Regulation was a success for France. The government had stressed since June 1989 that it was of the utmost importance to reach an agreement on the regulation before the end of December in order to achieve success during the French Pres- idency (which lasted during the second semester of 1989).$^{34}$ The British archival records show clearly that the last round of the negotiations (November-December 1989) was played between the Germans and them on the issue of national authorities' competences. ${ }^{35}$ France appeared as an honest broker determined to reach a compromise in good time.

However, most French decision-makers certainly had not anticipated that the first merger to be banned would target a French company. On 2 October 1991 the Commission banned the merger between the Franco-Italian company ATR and the Canadian De Havilland. This interdiction was seen as particularly problematic in France, as it threatened the emergence of a 'European champion' in high technology. For perhaps the first time, European competition policy created a political crisis in Paris, with members of parliament shouting 'Delors démission!' ('Delors, resignation!') in the French National Assembly. ${ }^{36}$ Ironically, according to George Ross, during the internal debate within the Commission, President of

\footnotetext{
${ }^{28}$ NA-FRG, B102/259100, note BMWi, 1 June 1965.

${ }^{29}$ EUA, BAC104/1993/159, Caspari to Brittan, 18 January 1989.

${ }^{30}$ EUA, BAC104/1993/160, note from the cabinet of Brittan, 12 April 1989.

${ }^{31}$ NA-FR, 1990.0452/26, notes SGCI, 28 September 1987 and 20 June 1988; 1990.0452/28, note SGCI, 14 December 1988.

32 NA-FR, 19900452/ 30, note sent to the Council of 21 December 1989.

${ }^{33}$ NA-FR, 19900452/30, note for the COREPER of 10 November 1989; 1990.0452/29, note of 11 October 1989.

${ }^{34}$ NA-FR, 19900452/28, note by the SGCI on 26 June 1989.

${ }^{35}$ NA-UK (FOIA), note DTI to Redwood, 1 December 1989.

${ }^{36}$ Minutes of the debates in the French National Assembly, 9 October1991,in Journal officiel,10 October 1991, pp.4335-7.
} 
the Commission Jacques Delors tried to oppose his colleague Leon Brittan's proposed decision to ban this merger. However, facing the prospect of being outvoted within the college of commissioners, he chose to abstain (Ross, 1995, pp. 178-80). This outcome is a spectacular illustration of the notion of 'unintended consequences', as most of the French officials negotiating the regulation did not anticipate such an outcome. As a result, on 15 November 1991, a note from the European Department insisted on the necessity to 'reexamine the functioning' of Regulation 4064/89 within the Council. ${ }^{37}$ To be fair, some French officials did voice concerns. In October 1989, Head of Treasury Jean-Claude Trichet warned that a merger regulation based on a com- petition-only criterion could 'hamper the formation of a competitive European industry' ${ }^{38}$ Political priorities, but also the path dependencies of Regulation $17 / 62$, limited the impact of this warning.

\section{Conclusion}

Regulation 17/62 was a critical juncture, as it created a path dependency for European competition policy by solving the uncertainties of the Treaty of Rome. Many alternatives to the institutional design finally chosen were seriously considered, such as associating the Member States to the decision-making process, setting up an independent authority or adopting the abuse principle. The balance of power at the end of 1960, at the beginning of the negotiation on the future Regulation, was not in favour of the solution of a double centralization (in terms of information and of decisions).

Regulation 17/62 created three long-term path dependencies that were difficult to over- come: the development of competition policy as an independent public policy regulated by its own criteria, a double centralization of the decision-making process under the Com- mission and the backlog. These three path dependencies influenced the negotiations of the Merger Regulation, and were interrelated with unintended consequences. The experience of the backlog was useful to alleviate the fear of a proactive European merger control pol- icy from France, but also for several German officials. This was a dramatic error in the French case, as the indignant reaction to the ATR/De Havilland merger illustrated. The notion of 'unintended consequences' also concerned the Commission, which did not anticipate the extent of the backlog problem in the 1960s. It was triggered partly by an un- anticipated consequence of the French insistence on targeting distribution agreements and of the Council's reluctance to grant block exemptions. Last, market-based dynamics were important but not sufficient. Overall, no single actor was able to dominate the process. French influence on both the implementation of Regulation $17 / 62$ and the adoption of Regulation 4064/89 has often been underestimated, as has been German reluctance to grant powers to the Commission in the 1960s.

Using primary sources is useful to test the notions of the long-term impact of path de- pendency and of 'unintended consequences'. It is a useful complement to previous studies which put an emphasis on market dynamics, such as the rise of neoliberal ideas or the pressure of business. It is helpful to understand the constraints of actors in their response to this changing context. Decision-makers took decisions taking into account economic, institutional, but also purely political factors, as the examples of France and Germany in 1989 demonstrate. This changing context interacted with long-term path dependencies to limit the alternatives available, and in the end to support the centralization process. However, this was not a mechanical process, as the failure of the negotiations remained an option. While it can appear logical today to have a centralized merger policy as a complement to the single market, this was not a preordained outcome.

\footnotetext{
${ }^{37}$ NA-FR, 5AG4/PHB7/1, note SGCI, 15 November 1991.

${ }^{38}$ NA-FR, 19900452/29, Trichet for the Minister, note of 4 October 1989.
} 


\section{References}

Akman, P. and Kassim, H. (2010) 'Myths and Myth-Making in the Institutionalization and Interpretation of EU Action: The Case of EU Competition Policy'. JCMS, Vol. 48, No. 1, pp. 111-32.

Armstrong, K. and Bulmer, S. (1998) The Governance of the Single European Market (Manchester: Manchester University Press).

Bouwens, B. and Dankers, J. (2010) 'The Invisible Handshake: Cartelization in the Netherlands, 1930-2000'. Business History Review, Vol. 84, No. 4, pp. 751-71.

Buch-Hansen, H. and Wigger, A. (2011) The Politics of European Competition Regulation: A Critical Political Economy Perspective (Oxon: Routledge).

Bulmer, S. (1994) 'Institutions and Policy Change in the European Communities: The Case of Merger Control'. Public Administration, Vol. 72, No. 3, pp. 423-44.

Bussière, E. (2007) 'La Concurrence’. In Dumoulin, M. (ed.) La Commission européenne, 1958-1972 (Brussels: European Community).

Büthe, T. (2007) 'The Politics of Competition and Institutional Change in European Union: The First Fifty Years'. In Meunier, S. and McNamara, K. (eds) Making History: European Integration and Institutional Change at Fifty (Oxford: Oxford University Press).

Büthe, T. and Swank, G. (2007) 'The Politics of Antitrust and Merger Review in the European Union: Institutional Change and Decisions from Messina to 2004'. Centre for European Studies Working Paper Series, 142.

Capoccia, G. and Kelemen, D. (2007) 'The Study of Critical Junctures: Theory, Narrative, and Counterfactuals in Historical Institutionalism’. World Politics, Vol. 59, No. 3, pp. 341-69.

Cini, M. and McGowan, L. (2009) Competition Policy in the European Union (Basingstoke: Palgrave Macmillan).

Commission of the European Communities (1962) 'Communication relating to the application of article 85 of the treaty to certain exclusive distribution agreements'. Official Journal, 113, 9 November, pp. 2627-8.

Commission of the European Communities (1987) Sixteenth report on competition policy (Luxembourg: Commission of the European Communities).

Dyson, K. and Featherstone, K. (1999) The Road to Maastricht: Negotiating Economic and Monetary Union (New York: Oxford University Press).

Fioretos, O. (2011) 'Historical Institutionalism in International Relations'. International Organization, Vol. 65, No. 2, pp. 367-99.

Gerber, D.J. (1998) Law and Competition in Twentieth Century Europe: Protecting Prometheus (Oxford: Clarendon Press).

Hall, P.A. and Taylor, R.R. (1996) 'Political Science and the Three New Institutionalisms'. Political Studies, Vol. 44, No. 5, pp. 936-57.

Hambloch, S. (2009) Europaïsche Integration und Wettbewerbspolitik. Die Frühphase der EWG (Baden-Baden: Nomos).

Jabko, N. (2006) Playing the Market: A Political Strategy for Uniting Europe, 1985-2005 (Ithaca: Cornell University Press). 
Kaiser, W. (2010) 'From Isolation to Centrality: Contemporary History Meets European Studies'. In Kaiser, W. and Varsori, A. (eds) European Union History. Themes and Debates (Chippenham: Palgrave Macmillan).

Kassim, H. and Menon, A. (2003) 'The Principal-Agent Approach and the Study of the European Union: Promise Unfulfilled?’. Journal of European Public Policy, Vol. 10, No. 1, pp.121-39.

McGowan, L. (2007) 'Theorising European Integration: Revisiting Neofunctionalism and Testing Its Suitability for Explaining the Development of EC Competition Policy'. European Integration Online Papers (EioP), Vol. 11, No. 3.

McGowan, L. (2010) The Antitrust Revolution in Europe. Exploring the European Commission's Cartel Policy (Cheltenham: Edward Elgar).

Montalban M., Ramirez-Perez S. and Smith, A. (2011) 'EU Competition Policy Revisited: Economic Doctrines Within European Political Work’. Cahiers du GREThA, Working Paper n²011-33.

Moravcsik, A. (1998) The Choice for Europe. Social Purpose and State Power from Messina to Maastricht (Ithaca, NY: Cornell University Press).

Patel, K.K. and Schweitzer, H. (eds) (2013) The Historical Foundations of EU Competition Law (Oxford: Oxford University Press).

Pace, L. and Seidel, K. (2013) 'The Drafting of Regulation 17. . A Hard-Fought Compromise' In Patel, K.K. and Schweitzer, H. (eds) The Historical Foundations of EU Competition Law (Oxford: Oxford University Press), pp. 54-88.

Pierson, P. (1996) 'The Path to European Integration. A Historical Institutionalist Analysis'. Comparative Political Studies, Vol. 29, No. 2, pp. 123-63.

Pitzer, F. (2009) Interessen im Wettbewerb. Grundlagen und frühe Entwicklung der europaïschen Wettbewerbspolitik, 1955-1966 (Stuttgart: Franz Steiner).

Pollack, M. (2003) The Engines of European Integration: Delegation, Agency, and Agenda Setting in the European Union (Oxford: Oxford University Press).

Riesenfeld, S.A. (1962) 'Antitrust Laws in the European Economic Community'. California Law Review, Vol. 50, No. 3, pp. 459-81.

Ross, G. (1995) Jacques Delors and European Integration (Cambridge: Polity Press).

Schulze, R. and Hoeren, T. (eds) (2000) Dokumente zum europaïschen Recht, Band 3: Kartellrecht (bis 1957) (Berlin: Springer).

Schwartz, E. (1993) 'Politics as Usual: The History of European Community Merger Control'. Yale Journal of International Law, Vol. 18, No. 2, pp. 607-62.

Steinmo, S. and Thelen, K. (1992) 'Historical Institutionalism in Comparative Politics'. In Longstreth, F., Steinmo, S. and Thelen, K. (eds) Structuring Politics: Historical Institutionalism in Comparative Analysis (Cambridge: Cambridge University Press).

Streeck, W. and Thelen, K. (2005) 'Introduction: Institutional Change in Advanced Political Econ- omies'. In Streeck, W. and Thelen, K. (eds) Beyond Continuity: Institutional Change in Advanced Political Economies (Oxford: Oxford University Press).

Warlouzet, L. (2011) Le Choix de la CEE par la France (1955-1969). Les débats économiques de Pierre MendèsFrance à Charles de Gaulle (Paris: Cheff).

Wilks, S. (2005) 'Agency Escape: Decentralization or Dominance of the European Commission in the Modernization of Competition Policy?'. Governance, Vol. 18, No. 3, pp. 431-52. 
Wilks, S. and Bartle, I. (2002) 'The Unanticipated Consequences of Creating Independent Competition Agencies'. West European Politics, Vol. 25, No. 1, pp. 148-72.

Witschke, T. (2009) Gefahr für den Wettbewerb? Die Fusionkontrolle der europaïschen Gemein-schaft für Kohle und Stahl und die ,,Rekonzentration“ der Ruhrstahlindustrie, 1950-1963 (Berlin: Akademie Verlag). 